\title{
Yellow fever virus isolated from a fatal post vaccination event: an experimental comparative study with the 17DD vaccine strain in the Syrian hamster (Mesocricetus auratus)
}

\author{
Vírus da febre amarela isolado de acidente pós-vacinal fatal: estudo experimental comparativo \\ com a amostra vacinal 17DD em Syrian hamsters (Mesocricetus auratus)
}

\author{
Sueli Guerreiro Rodrigues ${ }^{1}$, Amélia Paes de Andrade Travassos da Rosa ${ }^{2}$, Ricardo Galler ${ }^{3}$, Vera \\ Lúcia Reis de Souza Barros ${ }^{1}$, Conceição de Maria Almeida Vieira ${ }^{4}$, Jorge Fernando Soares \\ Travassos da Rosa ${ }^{1}$, Raimunda do Socorro da Silva Azevedo ${ }^{1}$, Márcio Roberto Teixeira Nunes ${ }^{1}$, \\ Elizabeth Salbé Travassos da Rosa ${ }^{1}$ and Pedro Fernando da Costa Vasconcelos ${ }^{1}$
}

\begin{abstract}
In order to investigate the pathogenicity of the virus strain GOI 4191 that was isolated from a fatal adverse event after yellow fever virus ( $\mathrm{YFV}$ ) vaccination, an experimental assay using hamsters (Mesocricetus auratus) as animal model and YFV 17DD vaccine strain as virus reference was accomplished. The two virus strains were inoculated by intracerebral, intrahepatic and subcutaneous routes. The levels of viremia, antibody response, and aminotransferases were determined in sera; while virus, antigen and histopathological changes were determined in the viscera. No viremia was detected for either strain following infection; the immune response was demonstrated to be more effective to strain GOI 4191; and no significant aminotransferase levels alterations were detected. Strain GOI 4191 was recovered only from the brain of animals inoculated by the IC route. Viral antigens were detected in liver and brain by immunohistochemical assay. Histothological changes in the viscera were characterized by inflammatory infiltrate, hepatocellular necrosis, and viral encephalitis. Histological alterations and detection of viral antigen were observed in the liver of animals inoculated by the intrahepatic route. These findings were similar for both strains used in the experiment; however, significant differences were observed from those results previously reported for wild type YFV strains.
\end{abstract}

Key-words: Yellow fever. Experimental study. Hamster. Pathogenicity.

\section{RESUM0}

Visando investigar a possível patogenicidade do vírus isolado (GOI 4191) de um evento adverso fatal pela vacinação antiamarílica, realizou-se um ensaio experimental em Syrian hamsters (Mesocricetus auratus), usando-se a cepa vacinal 17DD como parâmetro. As amostras virais foram inoculadas por via intracerebral, intra-hepática e subcutânea. Nos soros foram determinados níveis de viremia, resposta imune e aminotransferases, e nas vísceras a presença de vírus, antígeno e lesões teciduais. Não se detectou viremia para as duas amostras, a resposta imune foi maior para GOI 4191, e as aminotransferases não apresentaram alterações compatíveis com danos hepáticos. Nos animais inoculados por via intracerebral 0 vírus foi recuperado somente a partir do cérebro, sendo o antígeno viral detectado, por imuno-histoquímica, no cérebro e fígado. Infiltrado inflamatório e corpúsculos acidófilos foram observados no fígado e lesões tipo encefalite viral no sistema nervoso central. Alterações histológicas e antígeno viral foram observados, também, no fígado dos animais infectados por via intra-hepática, e ausentes naqueles inoculados por via subcutânea. Os resultados foram similares para as duas amostras testadas, entretanto distintos daqueles relatados na literatura para cepas silvestres do vírus amarílico.

Palavras-chaves: Febre amarela. Estudo experimental. Hamster. Patogenicidade.

\footnotetext{
1. Instituto Evandro Chagas, Belém, PA, Brasil. 2. Department of Pathology, University of Texas Medical Branch, Galveston, Texas, USA 3. Fundação Oswaldo Cruz, Rio de Janeiro, RJ, Brasil. 4. Universidade Federal Rural da Amazônia, Belém, PA, Brasil.

The present work was supported by grants from the IEC/FUNASA and CNPQ (process 521294/97-5).

Address to: Dra Sueli Guerreiro Rodrigues. Av. Almirante Barroso 492, Marco 66090-000 Belém, PA, Brasil.

Telefax: 5591 226-5262.

e-mail: suelirodrigues@iec.pa.gov.br
} 
The 17D yellow fever virus vaccine strain is recognized as one of the most successful vaccines in terms of efficacy and safety. This vaccine has rarely been associated with severe adverse events; the most commonly reported is post-vaccination encephalitis observed mostoften in children less than 10 months of age ${ }^{1115}$. Actually, only the 17D vaccine is produced to immunize humans againstyellow fever virus ( YFV) ; the vaccina derives from two distinct substrains, 17D-204 and 17DD, that correspond to different lineages obtained from the original YFV attenuated by Theiler and Smith ${ }^{8}$. In Brazil, the 17DD vaccine strain is currently used during vaccination campaigns, and is produced by the Institute of Technology in Immune Biologics ( Bio-Manguinhos)/ Oswaldo Cruz Foundation ( FIOCRUZ)/Rio de Janeiro. Saccharose and glutamate are used as stabilizing components 5 .

In 1999, a child residing in Goiania, Goias state died showing clinical manifestations similar to classic YFV infection; her illness was associated with a YFV vaccination adverse event ${ }^{20}$. The virus strain ( GOI 4191) obtained from clinical specimens of the patient, and YFVisolated from a second adverse vaccination eventreported in Americana/Sao Paulo state in 2000 were genetically identified as YFV 17DD vaccine strain ${ }^{620}$. In 2001, two additional fatal cases were reported in Belo Horizonte, MG, and in Três Passos/RS states (MS/FUNASA, data not shown). In addition, a suspicious fatal case was reported in Santos/SP and was supposed to be associated to YFV vaccination; however, the absence of specific clinical symptoms and the vaccine lot made it difficult to clarify ${ }^{6}$.

Additional adverse events similar to those that occurred in Brazil have been reported in other countries. Four cases ( 3 of them fatal) were described in the United States ${ }^{9}$, and 1 in Australia ${ }^{3}$. Moreover, one suspected case was also reported for each country in England ${ }^{1}, 1$ in Germany ${ }^{21}$ and 1 in Sweden ${ }^{19}$.

The occurrence of these post vaccination events with the YFV vaccine lead to an exhaustive surveillance and caution. This type of adverse event can be related to genetic factors that may regulate the cellular susceptibility to the YFV, emphasizing that an exacerbated susceptibility can result in severe clinical expression of the disease, but fortunately this condition seems to be extremely rare ${ }^{620}$.

The data presented is this study are related to an experimental assay using the Syrian hamster (Mesocricetus auratus) in order to investigate the viscerotropic activity of the virus strain GOI 4191. Hamsters have been used successfully as an alternative animal model in substitution to monkeys, to study YFV pathogenicity and treatment investigations ${ }^{1722}$.

\section{MATHERIAL AND METHODS}

Virus strains and inoculum. Vero cell cultures fluid infected with suspensions of heart fragments sampled from patients was used as virus stock for the strain GOI 4191. The Brazilian 17DD vaccine strain was used as virus reference to the experiment.

The vaccine vial ( lot: 98UFB088Z) was reconstituted with $5 \mathrm{~mL}$ of saline and apirogenic solution (lot: 99PDD284Z) to obtain the dose recommended to humans ( minimum of 1000 $\mathrm{LD}_{50} / 0.5 \mathrm{~mL}$ ) in $0.1 \mathrm{~mL}$, the final volume inoculated into hamsters. Virus strain GOI 4191 was diluted in phosphate buffered saline (PBS), pH 7.4, containing $0.75 \%$ bovine albumin and antibiotics (100U//mL of penicillin and $100 \mu \mathrm{g} /$ $\mathrm{mL}$ of streptomycin) to obtain a dose of $1000 \mathrm{LD}_{50} / 0.1 \mathrm{~mL}$. The virus samples were diluted immediately before the assay and kept on ice. Subsequently, samples of both virus suspensions were titrated in 2-3 days albino Swiss mice to confirm the dose administrated. Titers were calculated using the Reed \& Muench method ${ }^{14}$ and expressed in $\mathrm{L}_{50} / 0.02 \mathrm{~mL}$.

Hamster infection and specimen collection. Groups of 22 male hamsters, $4-5$ weeks old, and weighting $48 \mathrm{~g}$ in average, were inoculated with both virus strains, GOI 4191 and 17DD, by subcutaneous (SC), intrahepatic (IH), and intracerebral (IC) routes as shown in Table 1. A total of 22 animals were used as negative controls for the assay.

Table 1 - Number of inoculated hamsters according to the virus strain and route of inoculation.

\begin{tabular}{lcc}
\hline Routes & GOI 4191 & $17 \mathrm{DD}$ \\
\hline IC & 22 & 22 \\
IH & 22 & 22 \\
SC & 22 & 22 \\
\hline Total & 66 & 66 \\
\hline
\end{tabular}

For 10 consecutive days after infection, groups of animals containing 6 inoculated hamsters ( 2 IC, 2 IH, and 2 SC) and 1 normal were sacrificed daily. The animals surviving after 10 days were observed up to day 21, when all of them were sacrificed and the experiment concluded.

Under halothane anesthesia, hamsters were exsanguinated by cardiac puncture. The blood was obtained without anticoagulant substances and the serum separated and stored into two aliquots, one at $-20^{\circ} \mathrm{C}$ ( for serology) and another at $-70^{\circ} \mathrm{C}$ (attempts for virus isolation). Subsequently, animal necropsy was carried out to obtain samples of brain, liver, spleen, heart, kidney, and lung. The viscera were separated into two aliquots, one to be frozen at $-70^{\circ} \mathrm{C}$, and another preserved in $10 \%$ buffered formalin solution.

Virus testing. Sera and organ samples obtained from the infected hamsters were used for virus titration by inoculation in 2-3 day old albino Swiss mice. Each organ was individually

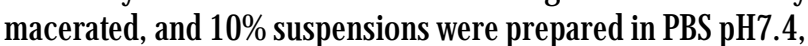
containing $0.75 \%$ bovine albumin and antibiotics $(100 \mathrm{UT} / \mathrm{mL}$ of penicillin and $100 \mu \mathrm{g} / \mathrm{mL}$ of streptomycin). Subsequently, the suspensions were clarified by centrifugation at 5,000 rpm for 15 minutes at $4^{\circ} \mathrm{C}$, and the supernatants used undiluted as inocula in newborn mice. Sera and viscera supernatant fluids giving positive results (death in mice) were then titrated in newborn mice, using 10 -fold serial dilutions prepared from $10^{-1}$ to $10^{-6}$. Virus titers were calculated using the Reed \& Muench method ${ }^{14}$ and expressed as $\mathrm{L}_{50} / 0.02 \mathrm{~mL}$

Antibody detection. Complement fixation test: the complement fixation test $\mathrm{CF}$ ) microtechnique modified by 
Fulton \& Dumbell ${ }^{4}$ was used for antibody detection, using known antigens. Serum samples obtained from inoculated hamsters and from the negative controls ( non inoculated hamster) were tested at dilutions of 1:8, 1:16; 1:32 and 1:64 againstYFV (strain 17DD) and Guaroa (strain BEH22063) virus antigens at 1:8 and 1:16 dilutions. Guaroa, a bunyavirus, was used as negative control. The CF antibody titers for positive sera were reported as the highest dilution giving a percentage of hemolysis up to $25 \%$.

Hemagglutination inhibition test: hamster sera, previously extracted by acetone method and adsorbed in goose erythrocytes, were tested by hemagglutination inhibition test (HI) using the microtechnique described by Shope ${ }^{16}$. Hemagglutinin antigens were prepared from YFV (strain 17DD) infected new born mouse brain, using the sucrose acetone extration method ${ }^{2}$. Initially, serum samples were tested at 1:20 dilution against 4 units of the antigen, and a 1:200 dilution of goose erytrocytes within $\mathrm{pH}$ 6.4. Subsequently, the titration of the positive sera was carried out up to 1:1,280 dilution.

Determination of alanine aminotransferase levels. Determination of alanine aminotransferase (ALT) level was determined in serum samples of hamsters previously inoculated with the YFV and controls, using a commercial kit (ROCHE) with an automated reader (COBRAS MIRA PLUS). ALT levels in the serum samples of hamsters collected from day 1 to day 10 and at day 21 post inoculation, were analyzed in function of the arithmetic average $(\Sigma(\mathrm{Xi}) / \mathrm{n})$ and standard deviation values found in the sera of hamsters not inoculated ( $71.5 \pm 11.0)$ used as negative control in the experiment as well as in correlation with hepatic parenchyma damage.

Antigen detection. Complement fixation test: samples of brain, liver, heart, spleen, kidney and lung obtained from the infected and non infected hamsters were individually macerated and used to prepare $1 \mathrm{~mL}$ of antigen suspension in veronal diluted at 1:5. The supernatants were clarified by refrigerated centrifugation at 2,500rpm for 5 minutes, and tested againstmouse immune ascitic fluid anti YFV (MIAF-YFV).

Immunohistochemical assay: fragments of organs obtained from infected hamsters were processed to obtain $5 \mu \mathrm{m}$ thin cuts, placed over glass slides Super-frost $® /$ Plus (A. Daigger \& Company), incubated at $60^{\circ} \mathrm{C}$, and processed by the immunohistochemical method ${ }^{7}$. The primary antiserum corresponded to the antiMIAF-YFV antibody diluted at $1: 4,000$, and the secondary (conjugated antibody) to mice and rabbit anti immunoglobulins produced in goat and absorbed in dextran polymer containing alkaline phosphatase molecules (Envision System, Dako, EUA). The cells with viral antigen showed discrete, moderate, or strong cytoplasmic staining (red) when examined using an Olympus CBA Microscope.

Histopathology. Tissues fragments were processed for light microscopy, using a standard technique described as sequential immersion of tissues in solutions with different ethanol concentrations from $70 \%$ up to absolute (100\%), followed by two passages in zylol solvent at room temperature, two immersions in paraffin resin at $60^{\circ} \mathrm{C}$, inclusion in paraffin blocks, $5 \mu \mathrm{m}$ thin cuts production using a rotating microtome (Jung Histocut 820 - Leica), and finally tissue staining, using the hematoxilin-eosin technique ${ }^{10} 13$.

\section{RESULTS}

The titers of the inocula for the GOI 4191 and 17DD virus strains corresponded to $10^{-2.3} \mathrm{LD}_{50} / 0.02 \mathrm{~mL}$ and $10^{-4.9} \mathrm{LD}_{50} /$ $0.02 \mathrm{~mL}$, respectively. Virus testing, by newborn mice inoculation method, revealed no viremia in hamster sera inoculated with both strains by IC, IH or SC routes. Virus was recovered only from the brain of animals inoculated by the IC route. The 17DD virus strain was recovered from brain samples between day 1 and day 9 post-inoculation (pi) revealing a maximum titer at day $3\left(10^{-3.4} \mathrm{LD}_{50} / 0.02 \mathrm{~mL}\right)$. Strain GOI 4191 was recovered from day 2 up to day 10 with highest titer detected at day $6\left(10^{-4} \mathrm{LD}_{50} / 0.02 \mathrm{~mL}\right)$ (Figure 1$)$.

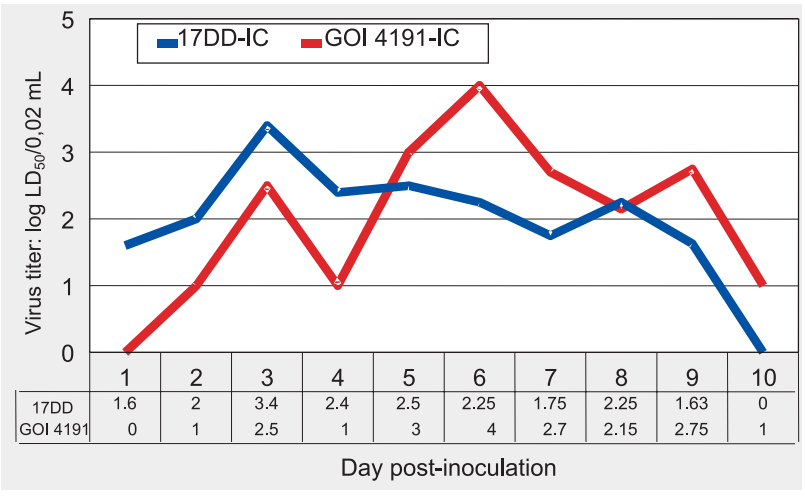

Figure 1 - Representative curve of virus detection in hamster brains inoculated by IC route with 17DD and GOI 4191 YFV strains.

Figure 2 shows the $\mathrm{HI}$ antibody responses in sera of hamsters inoculated with the 17DD strain 5 days pi by IC route, and at 6 days pi by IH and SC routes. On other hand, antibody for GOI 4191 strain was demonstrated at day 6 in hamsters inoculated by IH route and at day 7 in hamsters inoculated by IC and SC routes. Antibody titers could be detected up to day 21 pi. All of the samples obtained from the control animals were negatives.

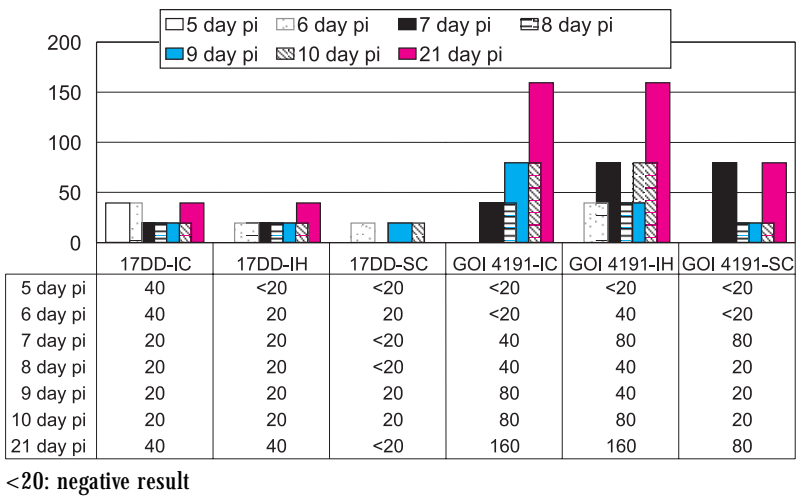

Figure 2 - HI antibody responses in hamsters inoculated with YFV strains 17DD and GOI 4191 by IC, IH and SC routes. 
Figure 3 shows the presence of $\mathrm{CF}$ antibodies produced against the 17DD YFV strain detected on the sixty day in animals inoculated by IC, IH and SC routes. On the fifth day, antibodies against the virus GOI 4191 were detected in animals inoculated by the IC route; and on the seventh day it was detected in animals inoculated by IH and SC routes.

Table 2 bring together the results concerning the determination of ALT levels, detection of viral antigen by immunohistochemical and histopathologic findings. Some ALT levels were found to be higher than $71.5+11.0$, values observed in samples obtained from animals inoculated with 17DD (IC and SC) and GOI 4191 (IC, IH, and SC) strains. Viral antigens were not detected for animals inoculated by SC route.

The test for viral antigen in organs of hamsters inoculated with 17DD and GOI 4191 viruses by the CF test using MIAFYFV ( BEH111) gave negative results for all samples, including brains from animals inoculated by the IC route. However, viral

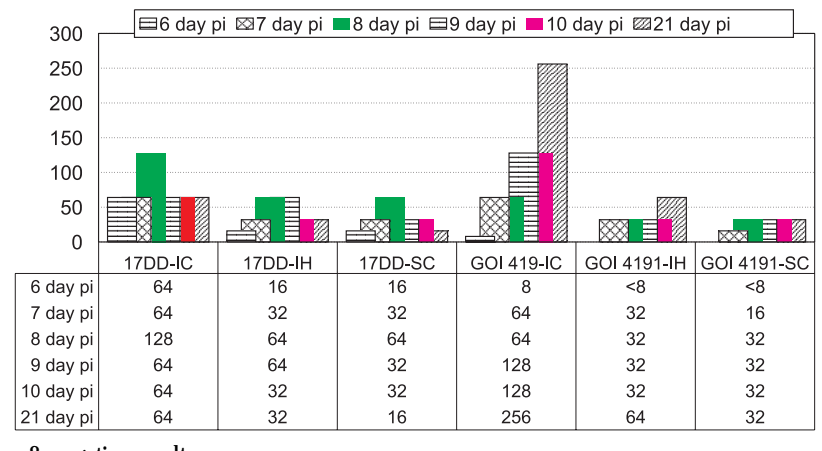

$<8$ : negative result

Figure 3 - CFantibody response in hamsters inoculated with 17 DD and GOI 4191 YFV strains by IC, IH and SC routes.

Table 2 - ALT levels in hamsters after infections with 17DD and GOI 4191 yellow fever strains and in uninfected (control) hamsters. Comparison with histopathologic evaluation and immunohistochenical detection of YF viral antigen.

\begin{tabular}{|c|c|c|c|c|c|c|c|}
\hline \multirow{3}{*}{ Day pi } & \multicolumn{7}{|c|}{$\mathrm{ALT}(\mathrm{UK} / \mathrm{mL})$} \\
\hline & 17DD & 17DD & 17DD & GOI 4191 IC & GOI $4191 \mathrm{IH}$ & GOI 4191 SC & C Controls \\
\hline & IC & $\mathrm{IH}$ & SC & IC & IH & SC & $71,5 \pm 11,0$ \\
\hline 1 & $55 \mathrm{~B}$ & $100 *$ & 57 & 69 IA & $86 \mathrm{~L}$ & 60 & 62 \\
\hline 2 & 74 B & 61 & 61 & 74 LA & $58 \mathrm{LA}$ & 75 & 64 \\
\hline 3 & $47 \mathrm{~B}$ & 59 & 67 & $54 \mathrm{IA}$ & $74 \mathrm{IA}$ & 83 & $215^{*}$ \\
\hline 4 & 53 B & 59 L\# & 63 & $56 \mathrm{~L}$ & 82 & 56 & 63 \\
\hline 5 & 49 B & $68 \mathrm{L \#}$ & 74 & 50 & 59 & 75 & 71 \\
\hline 6 & $44 \mathrm{BA}$ & 56:L\# & 81 & 72 & 56 & 60 & 72 \\
\hline 7 & $57 \mathrm{BA}$ & 48 & 71 & $30 \mathrm{~B}$ & 70 & 66 & 97 \\
\hline 8 & 42 BA LA & 56 & 65 & $87 \mathrm{~B}$ & 82 & 72 & 83 \\
\hline 9 & 35 BA LA & 45 & 96 & $57 \mathrm{BA}$ & 51 & 48 & 58 \\
\hline 10 & 43 BA LA & $711 *$ & $207 *$ & 99 B & 72 & 48 & 69 \\
\hline 21 & 41 & 47 & 68 & 45 & 42 & 57 & 76 \\
\hline \multicolumn{8}{|c|}{ B Histopathologic changes in brain. } \\
\hline \multicolumn{8}{|c|}{ L Histopathologic changes in liver. } \\
\hline \multicolumn{8}{|c|}{ A Immunohistochemical detection of YF viral antigen } \\
\hline \multicolumn{8}{|c|}{ \# Immunohistochemical detection of YF viral antigen was not performed. } \\
\hline
\end{tabular}

antigen was demonstrated by immunohistochemical assay in the brain and liver of animals inoculated by the IC route with both strains ( Figure 4A-C), as well as, in the liver of animals inoculated by the IH route with the strain GOI 4191 (Figure 4D). Immunohistochemical detection of YF viral antigen in the liver of the animals inoculated by IH route with the strain 17DD was not carried out.

Histopathologic examinations carried out in organs of hamsters collected from day 1 through day 10, and day 21 pi, revealed histologic changes in animals inoculated with the YFV 17DD and GOI 4191 strains by IC and IH routes. On the other hand, no histologic changes were found in animals inoculated by SC route.

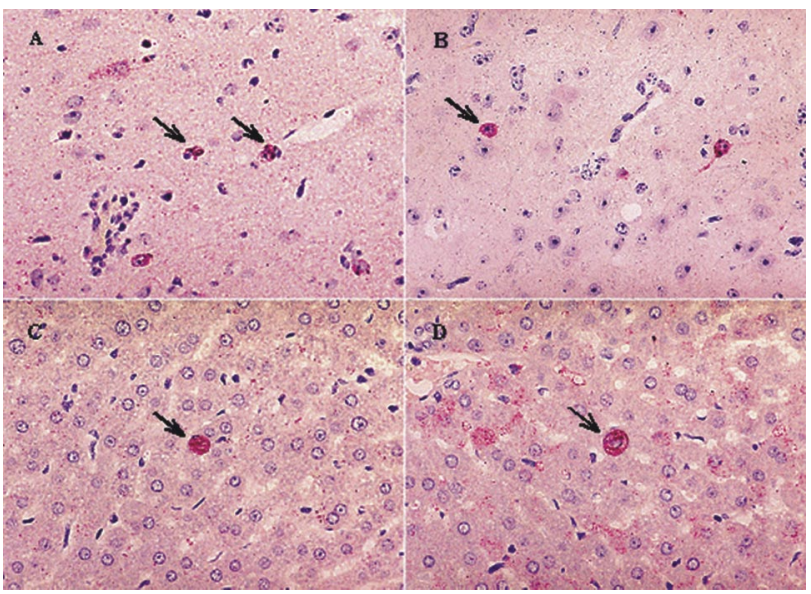

Figure 4 - Immunohistochemical staining (alkaline phosphatase) for YFviral antigen on brain and liver specimens of hamsters inoculated with the strains 17DD and GOI 4191. A. Brain from day6 pi with 17DD, routeIC, showingcytoplasm staining( red) in neuron cells (400X); B: Brain from day 9 pi with GOI 4191, routeIC, showingred stained YFVantigen in neuron cytoplasm (400X); C: Liverfrom day 10 pi with 17DD, routeIC, showingYFVantigen in hepatocyte cytoplasm strongly stained in red (400X); D: Liver from day 3 pi with GOI 4191 , routeIH, showing YFVantigen in several hepatocytes weakly stained in contrast with only one strongly stained.

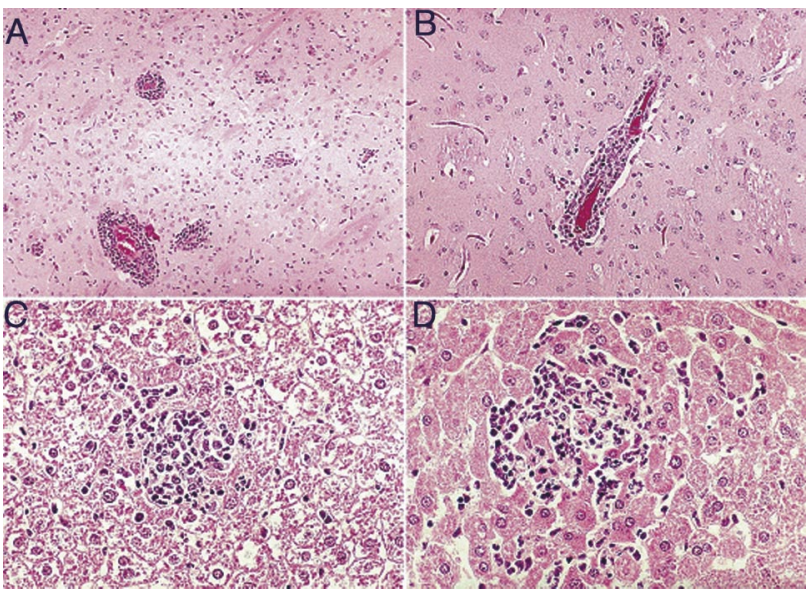

Figure 5 - Photomicrographs of pathologic changes ( hematoxylin-eosin) in brain and liver from yellow fever (17DD and GOI 4191 strains) infected hamsters. A: Brain from day 1 pi with 17DD, route IC, showing mononuclear inflammatory cell infiltrate in perivascular area (200X); B: Brain from day 9 pi with GOI 4191, route IC, showing discrete edema and mononuclear inflammatory cells infiltrate in the perivascular space (200X); C: Liver from day 6 pi with 17DD, route IH, showing tumefaction of hepatocytes and spotty necrosis (center of figure) surrounded by mononuclear inflammatory cells (400X); D: liver from day 1 pi with GOI 4191, route IH, showing focal necrosis of hepatocytes surrounded intralobular mononuclear inflammatory cells (400X). 
Hamsters inoculated IC with the 17DD virus showed viral encephalitis from day 1 to day 10 pi and liver inflammatoryinfiltrate from day 7 to day 10, whereas in hamsters infected with the GOI 4191 strain, virus encephalitis was observed from day 7 to day 10 pi, as well as liver inflammatory reaction from day 1 to day 4 ( Figure 5A-B). Animals inoculated with the 17DD and GOI 4191 by IH route showed morphologic changes in the liver from day 4 to day 6 and from day 1 to day 3 , respectively ( Figure 5C-D). Both strains produced viral encephalitis classified from light to severe, as well as discrete showed morphologic changes in the liver, described as mononuclear inflammatory reaction at lobule and portal space levels, and the presence of rare and isolated acidophilic granules.

\section{DISCUSSION}

No virus was detected in the sera of animals inoculated by any route, with either the 17DD or the GOI 4191 YFV strains. In contrast, differences could be observed in comparison with data previously reported for hamsters inoculated by intraperitoneal route with wild strains of YFV; the latter animals developed viremia within $24 \mathrm{~h}$ pi. The viremia lasted 5-6 days, and usually reached maximum values at day $3 \mathrm{pi}^{17}$. The $\mathrm{HI}$ and $\mathrm{CF}$ antibody curves for both strains were similar, although antibodies were initially detected at day 5-6 for the 17DD strain and at day 6-7 for the GOI 4191 virus strains. Furthermore, the highest antibody titers were induced by GOI 4191 strain. Early detection of $\mathrm{HI}$ antibodies (day 4 and day 5 pi) is reported for hamsters inoculated IP with a wild type YFV strain, as well as by IC and SC routes (APAT Rosa: unpublished data).

Complement-fixing antibodies were detected in hamsters inoculated IP with wild type YFV at day 4 and at day 6 pi by the SC route (APA Travassos da Rosa, unpublished data). In animals inoculated with the virus GOI 4191, complement-fixing antibodies were detected atday 6-7, but this type of antibody was also detected on day $6 \mathrm{pi}$ in animals inoculated with the 17DD virus strain. Yellow fever vaccine has been shown to induce seroconversion or significant complement-fixing antibody titer rises in up to $46 \%$ of persons with pre vaccination YFV or heterologous flavivirus experiences, but not in immunological virgins ${ }^{12}$.

Levels of ALT, specific aminotransferases usually indicative of hepatic necrosis, in hamsters infected with wild type YFV became elevated from day 4 to day 6 pi reaching levels of $1000 \mathrm{U} / \mathrm{L}$ considered higher than normal values (28-119U/L) reported for adult female hamsters ${ }^{17}$. In this study, ALT levels determined for hamsters inoculated with both virus strains showed differentcurve in comparison with the kinetic curves described above. In this case, enzyme levels showed ramdomized elevation, and according to results revealed by histophatology, correlation with hepatic parenchyma damage was not observed. ALT level alterations were not accentuated, except for hamsters inoculated with 17DD strain by IH and SC routes collected at tenth day pi. This finding probably was related to elevated hemolysis level observed in the tested sera.

The 17DD and GOI 4191 virus strains were recovered only from brain of hamsters inoculated by the IC route, the recognized organ for YFV vaccine strain tropism. Histopathologic results revealed characteristic encephalitis in animals inoculated with GOI 4191 by the IC route, and hepatic inflammatory reaction in hamsters inoculated by ICand IH routes. Same morphological changes were also observed in animals inoculated with 17DD vaccine strain. These findings are in contrast with previous one observed for animals inoculated with vaccine strains ${ }^{18}$. On the other hand, histological damage observed in hamsters inoculated IP with wild YFV strains were described as moderate and non specific morphologic changes in the brain (perivascular hemorrhage and edema), as well as hepatic focal necrosis at day 3 pi with confluent necrosis and steatosis evolution, where hepatocellular regeneration was observed in survived animals after day $8^{22}$.

YFV antigen determinations in organs of hamsters inoculated with 17DD and GOI 4191 strains were negative by CF test, including from the brain of animals inoculated IC; however the antigen was detected in fluids of infected Vero cells and brain of newborn mice infected with the referred strains ( data notshown). In contrast, viral antigen was demonstrated by immuno histochemical technique in organs ( brain and liver) of hamsters infected with 17DD and GOI 4191 strains.

Discrete differences observed for kinetic curves of virus detected in brain (Figure 1) and antibody levels (Figures $2 \mathrm{e}$ 3) observed early with 17DD virus, probably are related with the different doses used in the experiment. Nevertheless, further studies are necessary in order to adjust the $\mathrm{LD}_{50} \mathrm{GOI} 4191$ dose in comparison with the reference virus, as well as an experiment using groups of animals inoculated with the wild type YFV strain and used as positive control for virus viscerotropism.

The phenotypic analysis revealed that the virus strain GOI 4191, using hamsters as experimental model, showed similar results to those reported for the 17DD vaccine virus (lot98UFB088Z) and different from those found in the literature for hamsters inoculated with wild type YFV strains by IP route.

\section{AKNOWLEDGEMENTS}

To Dr. Maria da Luz Fernandes Leal, Bio-Manguinhos/ FIOCRUZ, who kindly provided the yellow fever virus vaccine vials (17DD substrain), Dr. Venâncio Avancini Ferreira Alves, Instituto Adolfo Lutz, for helping in immunohistochemical assay, and Dr. Robert B. Tesh, Department of Pathology/University of Texas Medical Branch, for his critical editing of the manuscript. The authors thank also Adlai Sousa for graphic computation support and Basilio Silva Buna, Elpídia do Socorro de Souza Costa, Francisca Nunes da Silva Nascimento, Helena Baldez Vasconcelos, Maria das Dores Miranda Barbosa, Maxwell Furtado de Lima, Raimunda do Socorro Rodrigues Pimentel and Walter Miranda Campos for technical support.

\section{REFERENCES}

1. Adhlyaman V, Oke A, Cefai C. Effects of yellow fever vaccination. The Lancet, 358: 1907-1908, 2001

2. Beaty BJ, Calisher $\mathrm{CH}$, Shope RE. Arboviruses. In: Schmidt NJ, Emmons RW (eds) Diagnostic Procedures for Viral, Rickettsial and Chlamydial 
Infections, $6^{\text {th }}$ edition, American Public Health Association, Washington $p$. 797-856, 1989 .

3. Chan RC, Penney DJ, Little D, Carter IW, Roberts JA, Rawlinson WD. Hepatitis and death following vaccination with 17D-204 yellow fever vaccine. The Lancet 358: 121-122, 2001

4. Fulton F, Dumbell KR. The serological comparison of strains of influenza virus. Journal of General Microbiology 3: 97-111, 1946.

5. Fundação Nacional de Saúde. Manual de vigilância epidemiológica dos eventos adversos após vacinação. Coordenação de Imunizações de auto-suficiência em Imunobiológicos. Ministério da Saúde, Brasília, 1998.

6. Galler R, Pugachev KV, Santos CLS, Ocran SW, Jabor AV, Rodrigues SG, Marchevsky RS, Freire MS, Almeida LFC, Cruz ACR, Yamamura AMY, Rocco IM, Rosa EST, Souza LTM, Vasconcelos PFC, Guirakhoo F, Monath TP. Phenotypic and molecular analyses of yellow fever 17DD vaccine viruses associated with serious adverse events in Brazil. Virology 290: 309-319, 2001.

7. Hall WC, Crowell TP, Watts DM, Barros VLR, Kruger H, Pinheiro F, Peters CJ. Demonstration of yellow fever and dengue antigens in formalin-fixed paraffin - embedded human liver by immunohistchemical analysis. American Journal Tropical Medicine Hygiene 45: 408-417, 1991.

8. Marianneau P, Georges-Courbot M-C, Deubel V. Rarity of adverse effects after 17D yellow-fever vaccination. The Lancet 358: 84-85, 2001.

9. Martin M, Tsai TF, Cropp B, Chang JG-J, Holmes DA, Tseng J, Shieh W-J, Zaki SR, Al-Sanouri I, Cutrona AF, Ray G, Weld LH, Cetron MS. Fever and multsystem organ failure associated with 17D-204 yellow fever vaccination: a report of four cases. The Lancet, 358: 98-104, 2001.

10. Michalany J. Técnica histológica em anatomia patológica: com instruções para cirurgião, enfermeira e citotécnico. Editora Pedagógica Universitária, São Paulo, 1998.

11. Monath TP. Yellow Fever: an update. Lancet Infectious Diseases 1: 11-20, 2001.

12. Monath TP, Craven RB, Adjukiewicz A, Germain M, Francy DB, Ferrara L, Samba E Mm, N'jie H, Chan K, Fitzgerald SA, Crippen PH, Simpson DIH,
Bowen ETW, Fabiyi A, Salaum J-J. Yellow fever in the Gambia, 1978-1979: Epidemiologic aspects with observations on the occurrence of orungo virus infections. American Journal Tropical Medicine Hygiene 29: 912-928, 1980.

13. Prophet EB, Mills B, Arrington JB, Sobin LH. Laboratory methods in histotechnology. American Registry of Pathology, Washington, 1992.

14. Reed LJ, Muench H. A simple method of estimating fifty per cent endpoints. American Journal of Hygiene 27: 493-497. 1938.

15. Robertson SE. The Immunological basis for immunization. 8. Yellow fever.: World Health Organization Document WHO/EPI/GEN/93.18, Geneva, 1993.

16. Shope RE. The use of a microhemagglutination-inhibition test to follow antibody response after arthropod-borne virus infection in a community of forest animals. Anais de Microbiologia, 11: 167-171, 1963.

17. Tesh RB, Guzman H, Rosa APAT, Vasconcelos PFC, Dias LB, Bunnell JE, Zhang H, Xiao S-Y. Experimental yellow fever virus infection in the Golden Hamster (Mesocricetus auratus) 1. Virologic, biochemical and immunologic studies. The Journal of Infectious Diseases 183 : 1431-1436, 2001.

18. Theiler M. The virus. In: Strode GK (ed) Yellow fever, McGraw-Hill, New York, p.39-136, 1951.

19. Troillet N, Laurencet $F$. Effects of yellow fever vaccination. The Lancet 358 : 1908-1909, 2001

20. Vasconcelos PFC, Luna EJ, Galler R, Silva LJ, Coimbra TL, Barros VLRS, Monath TP, Rodrigues SG, Laval C, Costa ZG, Vilela MFG, Santos CLS, Papaiordanou CMO, Alves VAF, Andrade LD, Sato HK, Travassos da Rosa ES, Froguas GB, Lacava E, Almeida LMR, Cruz ACR, Rocco IM, Santos RTM, Oliva OFP. Serious adverse events associated with yellow fever 17DD vaccine in Brazil: a report of two cases. The Lancet 358: 91-97, 2001.

21. Werfel U, Popp W. Effects of yellow fever vaccination. The Lancet 358: 1909, 2001

22. Xiao SY, Zhang H, Guzman H, Tesh RB. Experimental Yellow Fever Virus Infection in the Golden Hamster (Mesocricetus auratus). II. Pathology. The Journal of Infectious Diseases 183: 1437-1444, 2001. 